\title{
Migration and Population Patterns in the Parish of Torslev c. 1870-1901*
}

\author{
By HANS OLUF HANSEN \\ Institute of Statistics \\ University of Copenhagen
}

This research was conducted within the framework of 'Nordic Emigration', a project initiated in 1970 with financial aid from the Nordic Cultural Foundation (Nordisk Kulturfond). The main argument for establishing Nordic coordination in this field was to ensure comparability of the findings in order to reveal prospective common elements in migration patterns linked up with urbanization and massemigration to America.

1.

As the Danish research area was selected the parish of Torslev situated some 10 kilometers west of the provincial towns of Sæby and Frederikshavn and some 40 kilometers north east of Ålborg, the third-most of Danish provincial towns. The period considered is 1870-1901. Torslev was chosen for two reasons, firstly because the place is entirely rural in character, secondly because a heavy emigration overseas took place from this area. With respect to the level of emigration Torslev is a most atypical area. The existence of some 172.000 emigrant records as a tape dataset created on the initiative of Dr. K. Hvidt lead to selection of the three last decades of the 19th century as the research period. The emigrant dataset covers the period 1868-1899, thus it does not lead up to the general population census of 1901. Moreover this dataset only includes information on last residence before emigration on parish level for the counties (amter) of Hjørring and Svendborg; this constitutes another reason for selecting a parish in Northern Jutland as research area.

As far as means of documenting the prospective migrant stream from Torslev to urban districts is concerned, we are unfortunately in a rather bad position. National migratory movements were not included in the current registration prior to the advent of the general population registers in 1923-24. Sources

* Manuscript delivered to but not presented at Symposium. This account is an abridged and slightly modified version of a progress research report (same title) delivered to the session of Nordic Emigration in Oslo, March 13-15, 1973. 
of first rate importance are the general population censuses $(1870,1880,1890$, 1901), all including information on birth place. The 1901 census provides important additional information i.a. on last residence before in-migration to the parish and year of in-migration. Urbanization as a particular interesting aspect of national migration, consequently, may be studied by aid of census records from urban areas. A study of this type is being conducted by N. H. Frandsen for the railway town of Tølløse during 1860-1911. Military conscription rolls embracing serviceable males in ages $18-36$ is a poor substitute for general migration recods obtained for the total population by current registration. Finally, the available sources include ecclesiastical registrations of the movements of population, migration excluded. For the period under consideration these data categorie are usually of high accuracy and consistency.

Despite numerous shortcomings, the official statistics form a valuable background for the analysis. During the last 4 years highly efficient population registers have been developed on electronic basis at the Department of Statistics, Demographic Division, at Copenhagen University. Since these techniques have been outlined elsewhere ${ }^{1}$ they will not be dealt with here. Suffice it to say that practically no information was lost either in the manual process of excerption or due to inefficient principles of storage on the electronic devices. The data categories mentioned above may be handled either as separate datasets or at any level of integration. Efficient command of the data side obviously makes a very favourable research situation, especially in case of ultimately insufficient information.

2.

Did America with its vast ressources of arable land and scarcity of capital and labour prove a convenient outlet for Nordic surplus population after the Civil War? Or was the population growth in the Nordic countries mainly absorbed in the industrial and material take off experienced in this part of the world in about $1880-90$ ? In order to answer these questions obviously both population factors and economic conditions must be taken in consideration. For reasons of delimitation this research has been concentrated on the population factor.

The vital rates are illustrative of the general mortality decline since the late 18th century. So far no conclusive evidence has been given either in favour

1 Hans Oluf Hansen, Computer Methods for Production of Socio-Demographic Statistics, Cuadernos de Historia Economica de Cataluna VII, pp. 319-333, Barcelona (1972). Hans Oluf Hansen, Elektronregnemaskiner i befolknings-og bebyggelsesforskningens tjeneste, Arbejdspapir nr. 20, Det nordiske Ødegårdsprojekt, dansk afdeling (1972). Hans Oluf Hansen, Navnet som et socialt fænomen, Et eksempel på anvendelse af listestrukturer til administration af elektroniske befolkningsregistre, forthcoming in Proceedings from the NORNA Conference in Copenhagen, April 1973. 
of, or against conscious limitation of marital fertility in Denmark prior to the late 1880 's. The crude birth rate remained at a level well over 30 per 1000 mean population until the year 1900 .

The general mortality decline evident from the late 18th century bears witness of the far-reaching impact on the general living conditions caused by the great agricultural reforms from the year 1788. The importance of these reforms which lead to exchange of strip holdings for one compact holding, which paved the way for greatly increased efficiency in tilling methods and turned former leaseholdings into privately owned farms, is unprecedented in Danish history and can hardly be overestimated. By preventing more serious social and political tensions in the 19th century these reforms have contributed greatly in making the welfare society of 20 th century Denmark. ${ }^{2}$

During the period of 1870 -1901 less than one fourth of Danish population growth found an outlet through emigration. Taking the demographic transition in all Denmark as the currently best obtainable indicator of the long-term demographic development in Torslev, evaluation of the general state and change of the demographic settings in this parish during $1870-1901$ is achieved by expanding the census age structures 245 years ahead under vital conditions defined by the mortality and fertility schedules observed about census time and by comparing the empirical census age structures with the corresponding stable age structures emanating from those vital schedules. As currently best obtainable estimates of mortality and fertility at census time in Torslev and the rural part of Hjörring amt are used synthetic schedules calculated for rural districts in all Denmark over succeeding intercensus periods. Hopefully improved fertility and mortality estimates will be available for Torslev in near future through family reconstitution on basis of the parish register. From the properties of stable populations it follows that a given constant fertility schedule and diminishing mortality with the same difference of (a) at every age ultimately will constitute an age structure common to a subset of stable populations differing only with respect to levels of mortality and consequently to intrinsic rates of natural growth. ${ }^{3}$ The empirical equivalent to this class of stable populations have been labeled 'quasi-stable' populations. Not surprisingly the general state of population in Torslev during 1870-1901 approximated a situation of demographic quasi-stability.

For reasons of space only a few of the results from this part of the

2 A comprehensive cohort-oriented analysis of the Danish process of demographic transition is given by P. C. Matthiessen, Some Aspects of the Demographic Transition in Denmark (1970). Features of Danish economic growth are outlined by S. A. Hansen, Økonomisk vækst i Danmark 1720-1970 (1972). See also Otto Andersen, Dødelighedsforholdene i Danmark 1735-1840, forthcoming in National-økonomisk Tidsskrift 1973.

3 A. J. Coale, The Growth and Structure of Human Populations. A Mathematical Investigation, p. 40 (1972). Hans Oluf Hansen, Derivation of the Stable Population Model and Its Principal Properties, forthcoming in Cuadernos de Historia Economica de Cataluna 1973. 
analysis can be displayed here. In Fig. 1 are found very small deviations between the stable age structures on the one hand and the empirical census age structures of Torslev and rural districts in Hjørring amt on the other. From this fitness we learn, firstly, that the age specific fertility level must have

$\mathrm{T}$ a ble 1. Expected average of life at birth for each sex and intrinsic rates of reproduction.

$\begin{array}{lccc}\text { Component } & 1870-79 & 1880-89 & 1890-1900 \\ \text { (males) } & 48,26 & 49,80 & 51,51 \\ \begin{array}{l}\mathrm{e}_{o} \\ \text { (females) }\end{array} & 48,96 & 50,46 & 52,70 \\ \mathrm{e}_{o} & & & \\ \text { TFR } & 4,745 & 4,764 & 4,905 \\ \text { GRR } & 2,315 & 2,324 & 2,393 \\ \text { NRR } & 1,581 & 1,617 & 1,758 \\ \mathrm{X} & 31,83 & 31,67 & 31,51\end{array}$

been high a very long time up to the age of mass-emigration; secondly, that some movements in space are likely to have taken place in ages c. $20-$ c. 50 ; thirdly, that the net results of the geographical movements have been outmigration from the parish. Expected averages of life at birth and rates of reproduction are shown in Table 1. Estimates of mean age at first marriage are presented in Table 2.

$\mathrm{Table} 2$. Mean age at first marriage ${ }^{*}$ at census time for unions contracted before age 50 , the parish of Torslev and rural districts in Hjørring amt 1870, 1880, 1890, and 1901 .

\begin{tabular}{lccccccccc} 
& \multicolumn{1}{c}{ Mean age at first marriage } \\
& M & F & M & F & M & F & M & F \\
Torslev parish & 25,74 & 25,14 & 27,13 & 26,14 & 26,30 & 25,57 & 26,64 & 24,09 \\
Hjørring amt & 29,12 & 26,83 & 27,96 & 24,47 & 27,64 & 25,97 & 27,60 & 26,03
\end{tabular}

* Estimated from census statistics by the Hajnal method.

3.

Having touched on the demographic background and the historical interrelationships of fertility, mortality, and age structures in Torslev parish we may draw our attention to the components of migration. For the period under consideration the term migration exclusively embraces permanent changes of postal address across the parish border.

As mentioned above the main sources are updated census registers and a 
register of emigrants mostly bound for USA. The census registers are being updated with information on birth data $(1870,1880)$ for persons born in Torslev after Jan. 1, 1860; date of death $(1870,1880,1890)$; and date of outmigration overseas $(1870,1880,1890,1901)$. No final decision has been made as to updating with information on date of in- and/or out-migration taken from the military conscription rolls. Finally the census registers of 1870, 1880, and 1890 are being updated with information on presence at the other censuses.

From the updated census registers the net flows of in- and out-migrants may be determined for inter-census periods. A net in-migrant is a person not found in the preceeding census register and not born in the parish during the intervening period. A net out-migrant is a person who cannot be detected in the succeeding census register and who has not died in the parish during the intervening period. Consequently, both types of migrants are determined as residual groups. The emigrant dataset constitute a partial subset of the net out-migrant group. So far the flows of net migrants have not been determined at aggregate level on basis of the updated registers.

For reasons of space only verbal summaries may be given here of the results obtained so far. In general the migrant flow departing from rural areas increased very considerably from the 1860 's. In the period considered a point of culmination was reached in the 1880's. The out-migration from rural areas obviously led both to urbanization and emigration overseas. Due to deficiencies in the basic registrations of a great many emigrants it is uncertain so far if the main flow emigrated directly from rural districts or via urban areas. During the 1890's out-migration from rural areas slackened somewhat. The same is true of the emigration overseas. The levels of urbanization changed little in the 1860's. Slight increases are detected in the counties of Copenhagen, Svendborg, Vejle, and Århus. During the 1880's Århus became by far the leading area as to urban growth. This position was kept well ahead of any other county during the rest of the century. Heavy urban expansion occurred in the counties of Allborg and Odense during the 1890 's. Both at national level and at county level the Danish crude rates of overseas emigration conform to the European trends with culmination in the 1880's. The crude rates of out-migration from rural dictricts in Hjörring amt range among the highest observed during the whole period. In the same time urban growth was slow in this area. At the 1860 -census $8.7 \%$ of the population was resident in urban areas. By 1901 this proportion had Increased to $13.6 \%$. The crude rates of emigration, being relatively high in Hjörring amt, were even higher in the parish of Torslev. In the 1880's and 1890 's the crude rates of emigration from Torslev reached Swedish and Norwegian national levels. ${ }^{4}$ Estimates of age-specific net migration and emigration overseas for Torslev and all Hjörring amt are shown in Tables $3-6$.

4 A treatment of Danish emigration overseas from a humanistic-historical point of view is given by K. Hvidt, Flugten til Amerika (1971). 

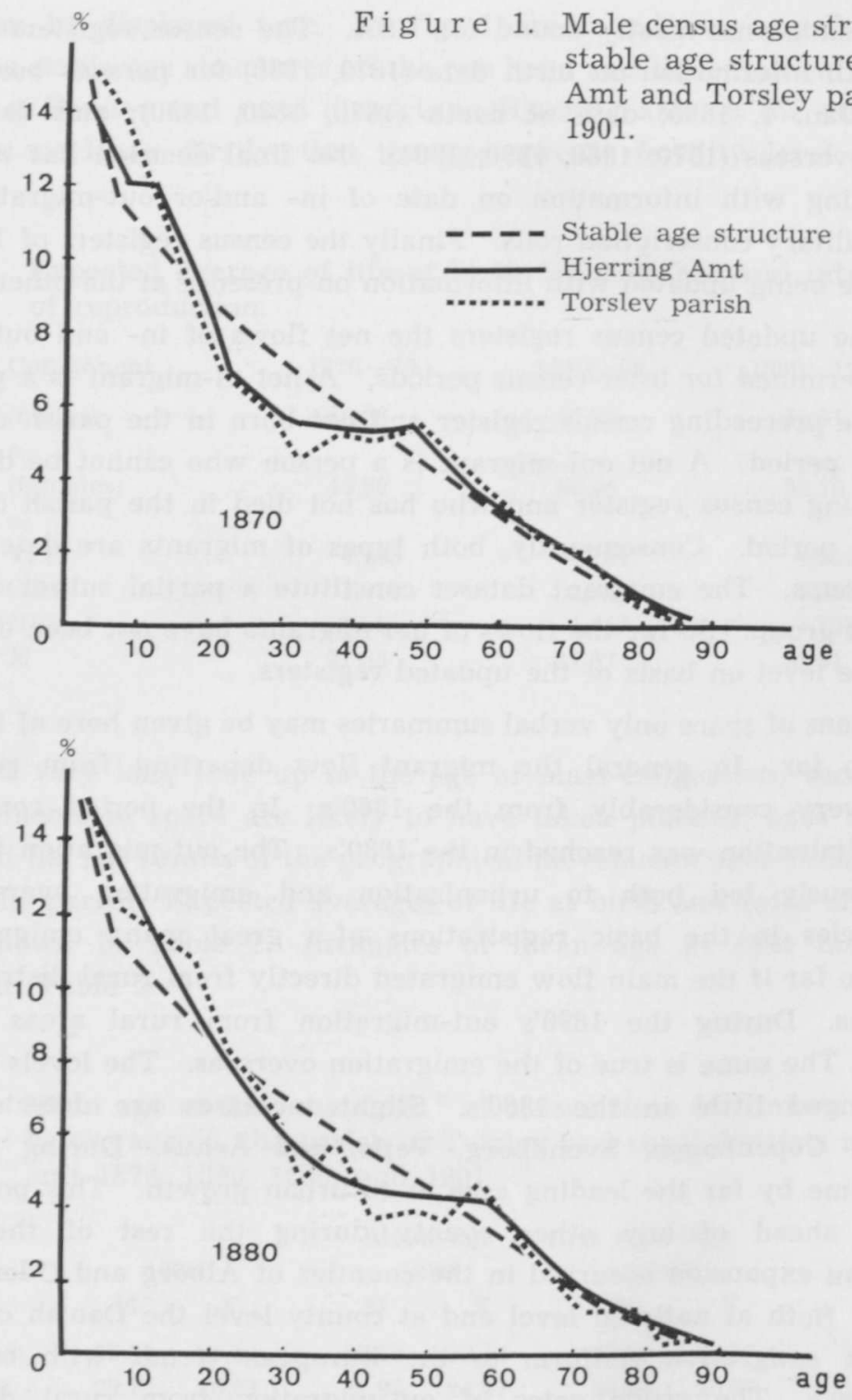

Inherent in the concept of net migration, whether computed as crude or age-specific rates, is an element of counter-factual inference: What would the absolute age distribution have been if the population had been closed under the prevailing vital conditions at census time? To a closed population infinite growth is unthinkable. Closing a population, other terms being equal, must be expected to effect a feed-back on the vital conditions i.e. the initial conditions for the projection. However, on the short sight and during the specific historical conditions closing the societies of Torslev parish and Hjörring amt 

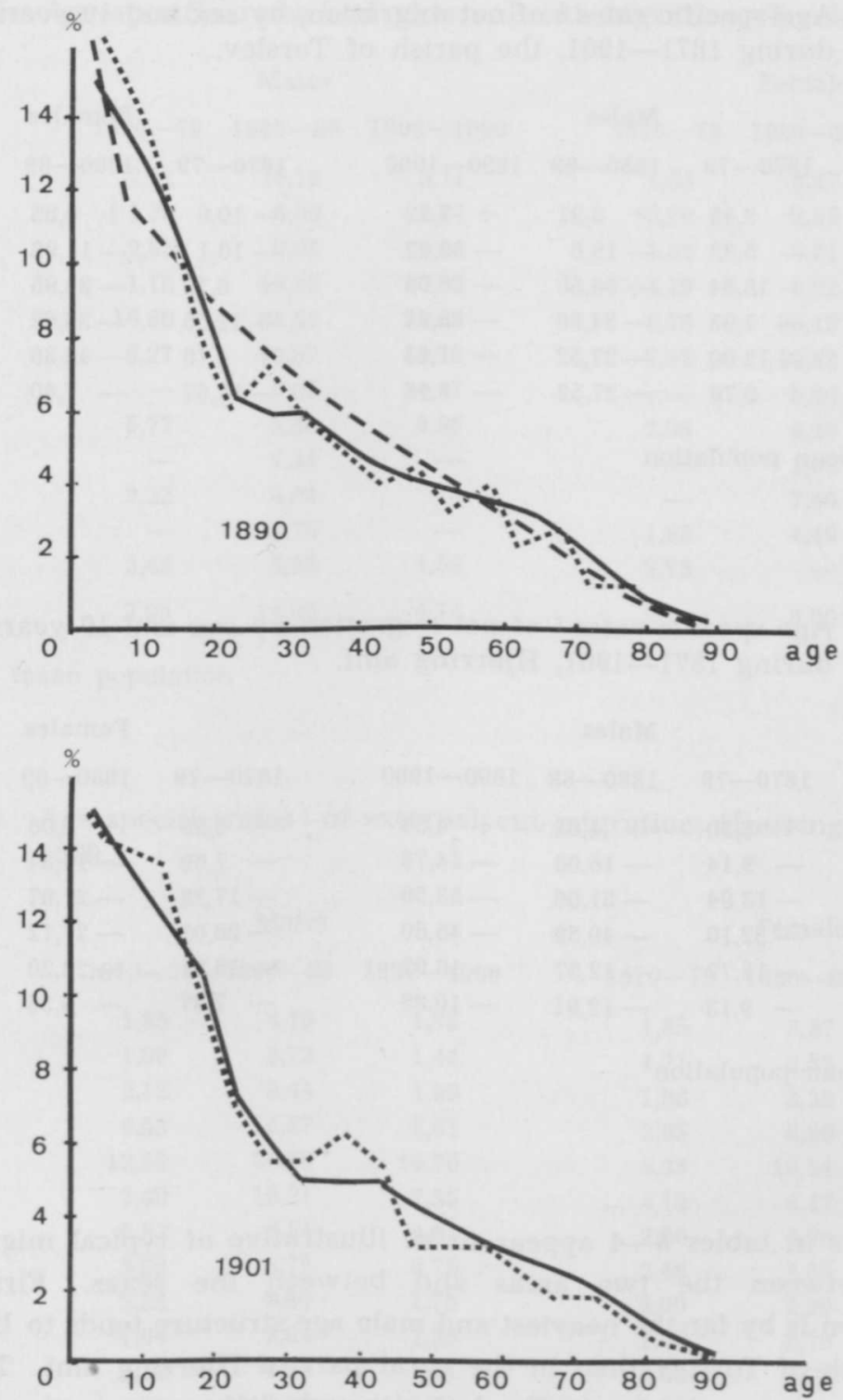

may be expected to have exerted a negligible feedback on the ruling vital conditions. This is the argument for calculating rates of net migration over intercensus intervals. Obviously the rates of net migration may be inflicted with errors due to incorrect estimates of the vital schedules and errors in census age reporting. Finally, exchanging cohort schedules for annual schedules may be a source to reduced precision. The results presented in tables $3-4$ are dependent of life tables only as ages $0-9$ have been excluded. Negative sign means surplus of out-migrants, positive sign indicates surplus of in-migrants. 
$\mathrm{T}$ a ble 3. Age-specific rates ${ }^{1}$ of net migration, by sex and 10 years intervals during 1871-1901, the parish of Torslev.

\begin{tabular}{lclcccc} 
Age & \multicolumn{3}{c}{ Males } & \multicolumn{3}{c}{ Females } \\
& $1870-79$ & $1880-89$ & $1890-1900$ & $1870-79$ & $1880-89$ & $1890-1900$ \\
$10-14$ & $+8,45$ & $+8,91$ & $+3,52$ & $-10,0$ & $+0,85$ & $-4,36$ \\
$15-19$ & $-5,32$ & $-19,0$ & $-30,62$ & $-10,1$ & $-11,98$ & $-5,02$ \\
$20-24$ & $-18,84$ & $-58,50$ & $-63,95$ & $+6,70$ & $-30,95$ & $-41,97$ \\
$25-29$ & $-7,93$ & $-34,90$ & $-35,71$ & $-32,05$ & $-36,62$ & $-32,91$ \\
$30-34$ & $-12,00$ & $-27,52$ & $-1,63$ & $+4,76$ & $-46,38$ & $-8,26$ \\
$35-39$ & $+0,76$ & $-27,52$ & $-6,56$ & $-16,67$ & $-7,40$ & $-24,35$
\end{tabular}

1 per 1000 mean population

$\mathrm{T}$ a ble 4. Age-specific rates ${ }^{1}$ of net migration by sex and 10 years intervals during 1871-1901, Hjørring amt.

\begin{tabular}{lcccccc} 
Age & \multicolumn{3}{c}{ Males } & & \multicolumn{3}{c}{ Females } \\
& $1870-79$ & $1880-89$ & $1890-1900$ & $1870-79$ & $1880-89$ & $1890-1900$ \\
$10-14$ & $+6,30$ & $+4,62$ & $+4,54$ & $+3,99$ & $+3,06$ & $+9,67$ \\
$15-19$ & $-9,14$ & $-16,08$ & $-14,76$ & $-7,00$ & $-17,34$ & $-6,74$ \\
$20-24$ & $-13,94$ & $-51,06$ & $-53,56$ & $-17,28$ & $-27,07$ & $-25,17$ \\
$25-29$ & $-32,10$ & $-40,59$ & $-45,60$ & $-20,02$ & $-27,12$ & $-20,52$ \\
$30-34$ & $-12,77$ & $-12,97$ & $-16,92$ & $-15,21$ & $-22,20$ & $-35,29$ \\
$35-39$ & $-9,13$ & $-12,91$ & $-10,85$ & $-7,57$ & $-9,33$ & $-21,14$
\end{tabular}

1 per 100 mean population

The rates in tables 3-4 appear to be illustrative of typical migration differences between the two areas and between the sexes. Firstly, male net migration is by far the heaviest and male age structure tends to be younger in the parish of Torslev than in the rural part of Hjørring amt. The female net migration is heavier too in Torslev, although differences in the female age structures tends to be indecisive. Secondly, the females seem to be older than males in out-migration; the male net migration culminates in age $20-24$, whereas female net migration is found to be heaviest in age $25-29$ during the 1870 's, and 1880's. During the 1890's, however, the female migrants became comparatively younger. Half of the census populations in the period considered were born in Torslev parish. Consequently, the rates of net migration for Torslev may confidently be interpreted primarily in terms of out-migration.

The age-specific rates of overseas emigration from Torslev and all Hjørring amt are shown in Tables 5-6. If these rates (i.e. the basic registrations) and the rates of net migration are correct, heavy outflows of females during 
Table 5. Age-specific rates ${ }^{1}$ of external out-migration, Torslev 1870-99.

\begin{tabular}{rrrrrrr}
\multicolumn{1}{c}{ Age } & \multicolumn{3}{c}{ Males } & \multicolumn{3}{c}{ Females } \\
$0-4$ & $1870-79$ & $1880-89$ & $1890-1900$ & $1870-79$ & $1880-89$ & $1890-1900$ \\
$5-9$ & 2,11 & 10,18 & 3,11 & 1,35 & 9,47 & 1,53 \\
$10-14$ & 1,39 & 6,36 & 1,74 & 0,78 & 2,85 & 1,79 \\
$15-19$ & 2,83 & 5,65 & 0,64 & 1,02 & 6,81 & 1,97 \\
$20-24$ & 1,10 & 19,10 & 10,96 & 4,19 & 9,22 & 6,64 \\
$25-29$ & 18,80 & 38,62 & 24,65 & 8,78 & 26,19 & 10,27 \\
$30-34$ & 6,27 & 30,87 & 11,78 & 7,42 & 12,68 & 5,89 \\
$35-39$ & - & 9,09 & 4,47 & - & 5,80 & 1,49 \\
$40-44$ & 5,77 & 5,56 & 2,96 & 2,06 & 9,26 & 1,61 \\
$45-49$ & - & 7,41 & - & - & 1,82 & 1,58 \\
$50-54$ & 2,22 & 4,82 & - & - & 7,50 & 1,87 \\
$55-59$ & - & 2,78 & - & 1,93 & 4,49 & 4,15 \\
& 2,45 & 4,55 & 4,58 & 2,73 & - & 2,80
\end{tabular}

1 Per 1000 mean population

T a b l e 6. Age-specific rates ${ }^{1}$ of external out-migration, Hjørring amt 18701899.

\begin{tabular}{rcrcccc}
\multicolumn{1}{c}{ Age } & \multicolumn{3}{c}{ Males } & \multicolumn{3}{c}{ Females } \\
& $1870-79$ & $1880-89$ & $1890-1900$ & $1870-79$ & $1880-89$ & $1890-1900$ \\
$0-4$ & 1,85 & 4,19 & 1,75 & 1,85 & 3,87 & 2,00 \\
$5-9$ & 1,89 & 2,72 & 1,44 & 1,71 & 2,55 & 1,61 \\
$10-14$ & 2,12 & 3,44 & 1,99 & 1,96 & 3,38 & 1,61 \\
$15-19$ & 4,53 & 11,37 & 8,61 & 2,95 & 6,96 & 5,52 \\
$20-24$ & 13,58 & 24,66 & 16,70 & 5,35 & 10,54 & 8,57 \\
$25-29$ & 7,40 & 15,21 & 7,35 & 4,12 & 8,47 & 5,02 \\
$30-34$ & 5,53 & 6,54 & 4,81 & 2,80 & 4,98 & 3,09 \\
$35-39$ & 3,68 & 5,75 & 2,75 & 2,48 & 3,66 & 1,56 \\
$40-44$ & 2,22 & 3,80 & 1,75 & 2,00 & 2,60 & 1,90 \\
$45-49$ & 1,94 & 2,64 & 1,25 & 1,62 & 2,79 & 1,35 \\
$50-54$ & 2,12 & 1,85 & 1,21 & 2,03 & 2,75 & 1,41 \\
$55-59$ & 2,12 & 2,33 & 1,72 & 1,58 & 2,46 & 1,60 \\
& 3,68 & 7,05 & 3,76 & 2,44 & 4,86 & 2,90
\end{tabular}

1 Per 100 mean population

1870-1901 and of males particularly during the 1880's and 1890's are detected. To a very considerable extent these outflows must have had destinations internal to the national border and external to the parish border. These destinations are most likely to have been surrounding parishes and urban areas. In Torslev the rates of net migration seem to have increased for both sexes 
during the whole period, despite heavy decrease in overseas emigration during the 1890's. Torslev and the other rural districts in Hjørring amt may have made substantial constributions to the urban growth of Alborg during this decade. In conclusion the migratory movements suggested by the stable population analysis seem to be supported.

The impression of out-migration (i.e. movement across the parish border) as the most important migration element in the Torslev area is firmly supported by the census populations distributed by birth place. In $187055,6 \%$ of the resident population was born within the parish and $93.4 \%$ within Hjørring amt. During the period of $1870-1901$ these proportions varied within ranges of $52.6 \%-55.6 \%$ and $90.6 \%-93.9 \%$ respectively. The out-migration from Torslev was compensated mostly through in-migration from near-by districts. Another remarkable feature is the existence of a certain in-migration from Sweden ranging from 4 to 11 persons in each census register. A parallel is the Swedish labour migration to Lolland-Falster during the late 19th century. From the turn of the century labour in-migration from Poland may have taken place as well. No Poles have been recognized in the census registers of Torslev during 1870 - 1901. In conclusion the distributions by birth place are indicative of considerable constancy of the geographical patterns of in-migration to Torslev. Until the year 1879 the overseas emigration from Torslev was indirect in character. The emigrants were handled by foreign shipping companies via foreign ports. With the advent of the Danish America-line of Thingvalla in $1880,13 \%$ of the overseas emigration during the 1880 's became direct i.e. performed via Danish ports. In the 1890's the Thingvalla line encroached on the transport market in Northern Jutland. During this decade $51 \%$ of the overseas out-migration was negotiated by the national line which at that time suffered badly in competition with the English, German and French giant companies on the Atlantic transport market. The Thingvalla line regularly called at the port of Frederikshavn. ${ }^{5}$

4.

Due to actual occurrence of empirical approximations to quasi-stable populations during some decades prior to the general fertility decrease which was linked up with the demographic transition, stable population theory obviously is well suited for purposes of estimation in countries with incomplete data. Estimation, however, has not been the main application of stable populations in this account since life tables and fertility schedules for rural areas may be easily obtained for rural districts in all Denmark for the period $1871-1900$.

5 A fascinating account of emigrant agencies as an aspect of the transatlantic passenger transport system is given by Berit Brattne, Bröderna Larsson. En studie i svensk emigrantagenturvirksomhet under 1800-tallet (1973). See also K. Hvidt, op. cit. pp. $409 \mathrm{ff}$. 
Our principal concern was investigation of the interaction of the vital schedules and actual census age structures from Northern Jutland, more especially Torslev parish, in order to reveal features that must have been essential to the more distant demographic settings for the general exodus from rural districts to urban areas and to overseas countries during the latter half of the 19 th century. The migratory movements suggested by comparing stable and empirical age structures were closer examined. The rates of net migration apparently could be interpreted mainly in terms of out-migration across the parish border. Of the out-migrants a great part emigrated during the 1880's whereas in the 1890's a great many persons are likely to have sought to the near-by provincial town of Alborg adding to the rapid urbanization here. An increasing proportion of the overseas emigration from Torslev was transported on Danish keel after the advent of the Thingvalla-line in the year 1880 . Distributing the census populations by birth place indicated considerable constancy as to geographical patterns of in-migration to Torslev. By far the great part of the in-migrants came from near-by parishes. 